\title{
RESUME PENGERTIAN METODELOGI ANALISIS DALAM PENGEMBANGAN SUATU SISTEM
}

\author{
Muhammad lubis angsori \\ 175100026 \\ Fakultas Komputer \\ Prodi : Sistem Informasi \\ Universitas Mitra Indonesia \\ muhammadlubisangsori.student@umitra.ac.id
}

\begin{abstract}
Pada Era Teknologi sekarang, sistem sering digunakan untuk mempermudah manusia untuk melakukan segala pekerjaan atau kegiatan baik dari berbelanja, belajar hingga bekerja.

Pengembangan Sistem merupakan salah satu teknik dalam membuat penyususnan suatu sistem yang baru untuk menggantikan sistem yang lama secara keseluruhan atau memeprbaiki sistem yang telah ada.

Metodelogi Analisis adalah yang digukan untuk memperoleh kebenaran menggunakan penelusuran dengan cara tertentu dalam menemukan kebenaran, metodelogi tersusun dari cara cara yang terstruktur untuk memperoleh ilmu
\end{abstract}

Kata Kunci : Pengertian Metodelogi Analisis. 


\section{A. PENDAHULUAN}

Materi Kuliah audit sistem informasi, Section 01 Membahas Tentang ketertarikan audit, sistem dan metodologi, membahas mengenai pengertian audit, pengertian sistem, pengertian informasi, pengertian audit sistem informasi, dan pengertian metodelogi analisis dalam pembahasna kali ini saya akan meresume materi audit sistem informasi secion 01 tentang pengertian metodelogi analisis

\section{B. PEMBAHASAN / STUDI KASUS}

Pengertian Metodelogi

Analisis, dalam pengertian untuk pengembangan sistem menggunakan metodelogi analisis dan disain terstruktur (structured system analysis and design). metodelogi analisis dan desain tersetruktur adalah metodelogi yanga digunakan dalam tahap analisis dan tahap desain. metodelogi ini termasuk kedalam kelompok data oriented methodologies yang menekankan kepada karakteirsttik dari data yang akan diproses, lebih sepesisfik metodelogi snslidid dsn desin terstruktur masuk kedalam kategori data flowariented 


methodologies dimana
metodelogi ini didasarkan
kepada pemecahan dari
sistem kedalam modul-
modul berdasarkan tipe
elemen data dan
tingkahlaku logika tersebut
didalam sistem dengan
metodelogi ini sistem dapat
digambarkan secara logika
dan digambarkan secara
logika dari arus data dan
hubungan antar fungsinya
didalam modul-modul di
sistem (jogiyanto,2005)

- Tahap Metodelogi Analisis

1. kebijakan dan perancangan sistem

2. analisis sistem

3. desain sistem

4. implementasi sistem

- Model-Model Metodelogi Pengembangan Software

1. Skuensial Linier Atau Model Waterfall
Development Model

2. Model Prototype

3. Model Rappid

Application Development (RAD)

4. Model Evolutionary

Devlopmen

\section{KESIMPULAN}

Dari pembahasan di atas dapat disimpulkan pengembangan sistem akan lebih mudah, lebih terstruktur dan tergambar apabila kita menggunakan pengembangan dengan metodelogi analisi

D. DISKUSI

Saya membaca dan membahas pengertian metodelogi analisis melalui beberapa referensi yang mengenai pengertian metodelogi analisis, pengembangan metodelogi analis sangat penting untuk memperoleh kebenaran menggunakan penelusuran 
dengan cara tertentu dalam menemukan kebenaran dan pemecahan dari sistem kedalam modul-modul berdasarkan tipe elemen data dan tingkahlaku logika tersebut didalam sistem dengan metodelogi ini sistem dapat digambarkan secara logika dan digambarkan secara logika dari arus data dan hubungan antar fungsinya.

\section{E. REFERENCE}

[1]

O. M. Febriani and A. S. Putra, "Sistem Informasi Monitoring Inventori Barang Pada Balai Riset Standardisasi Industri Bandar Lampung," J. Inform., vol. 13 , no. 1 , pp. 90-98, 2014.

[2] A. S. Putra, "Paperplain: Execution Fundamental Create Application With Borland Delphi 7.0 University Of Mitra Indonesia," 2018.

[3] A. S. Putra, "2018 Artikel Struktur Data, Audit Dan
Jaringan Komputer," 2018.

[4] A. S. Putra, "ALIAS MANAGER USED IN DATABASE DESKTOP STUDI CASE DB DEMOS."

[5] A. S. Putra, "COMPREHENSIVE SET OF PROFESSIONAL FOR DISTRIBUTE COMPUTING."

[6] A. S. Putra, "DATA ORIENTED RECOGNITION IN BORLAND DELPHI 7.0."

[7] A. S. Putra, "EMBARCADERO DELPHI XE 2 IN GPUPOWERED FIREMONKEY APPLICATION."

[8] A. S. Putra, "HAK ATAS KEKAYAAN INTELEKTUAL DALAM DUNIA TEKNOLOGY BERBASIS REVOLUSI INDUSTRI 4.0."

[9] A. S. Putra, "IMPLEMENTASI PERATURAN PERUNDANGAN UU. NO 31 TAHUN 2000 TENTANG DESAIN INDUSTRI BERBASIS INFORMATION TECHNOLOGY."

[10] A. S. Putra, 
"IMPLEMENTATION OF PARADOX DBASE."

[11] A.

$S$.

Putra, "IMPLEMENTATION OF TRADE SECRET CASE STUDY SAMSUNG MOBILE PHONE."

[12] A.

S. Putra, "IMPLEMENTATION PATENT

FOR APPLICATION WEB BASED CASE STUDI WWW. PUBLIKLAMPUNG. COM."

[13] A.

S. Putra "IMPLEMENTATION SYSTEM FIRST TO INVENT IN DIGITALLY INDUSTRY."

[14] A. S. Putra, "MANUAL REPORT \& INTEGRATED DEVELOPMENT

ENVIRONMENT BORLAND DELPHI 7.0."

[15] A. S. Putra, "PATENT AS RELEVAN SUPPORT RESEARCH."

[16] A. S. Putra, "PATENT FOR RESEARCH STUDY CASE OF APPLE. Inc."

[17] A. S. Putra, "PATENT PROTECTION FOR APPLICATION INVENT."
[18] A. S. Putra, "QUICK REPORT IN PROPERTY PROGRAMMING."

[19] A. S. Putra, "REVIEW CIRCUIT LAYOUT COMPONENT REQUIREMENT ON ASUS NOTEBOOK."

[20] A. S. Putra, "REVIEW TRADEMARK PATENT FOR INDUSTRIAL TECHNOLOGY BASED 4.0."

[21] A. S. Putra, "TOOLBAR COMPONENT PALLETTE IN OBJECT ORIENTED PROGRAMMING."

[22] A. S. Putra, "WORKING DIRECTORY SET FOR PARADOX 7."

[23] A. S. Putra, "ZQUERY CONNECTION IMPLEMENTED PROGRAMMING STUDI CASE PT. BANK BCA Tbk."

[24] A. S. Putra, D. R. Aryanti, and I. Hartati, "Metode SAW (Simple Additive Weighting) sebagai Sistem Pendukung Keputusan Guru Berprestasi (Studi Kasus: SMK Global 
Surya)," in Prosiding Seminar

Nasional Darmajaya, 2018,

vol. 1, no. 1, pp. 85-97.

[25] A. S. Putra and 0.

M. Febriani, "Knowledge

Management Online

Application in PDAM

Lampung Province," in

Prosiding International

conference on Information

Technology and Business

(ICITB), 2018, pp. 181-187.

[26] A. S. Putra, O. M. Febriani, and B. Bachry, "Implementasi Genetic Fuzzy System Untuk Mengidentifikasi Hasil Curian Kendaraan Bermotor Di Polda Lampung," SIMADA (Jurnal Sist. Inf. dan Manaj. Basis Data), vol. 1, no. 1, pp.
21-30, 2018.

[27] A. S. Putra, H. Sukri, and K. Zuhri, "Sistem Monitoring Realtime Jaringan Irigasi Desa (JIDES) Dengan Konsep Jaringan Sensor Nirkabel," IJEIS (Indonesian J. Electron. Instrum. Syst., vol. 8, no. 2, pp. 221-232.

[28] D. P. Sari, O. M. Febriani, and A. S. Putra, "Perancangan Sistem Informasi SDM Berprestasi pada SD Global Surya," in Prosiding Seminar Nasional Darmajaya, 2018, vol. 1, no. 1, pp. 289-294. 